\title{
MIGRANT WORKERS EMPOWERMENT THROUGH VOCATIONAL EDUCATION AND COMMUNITY-BASED LEARNING: A Study Case of Indonesian In Taiwan
}

\author{
Paulus Rudolf Yuniarto \\ Research Center for Area Studies, \\ Indonesian Institute of Sciences, Jakarta, Indonesia \\ Email: rudolfyuniarto@gmail.com
}

\begin{abstract}
Based on the observation of Indonesian migrant workers vocational training programs and communitybased learning activities in Taiwan, the training programs play a part in assisting migrant workers to improve their skill and develop self-capacity building, to facilitate knowledge transfer and offer guidelines on productive financial management to migrant workers, and to introduce and develop intercultural communication with locals. However, financial and material support from stakeholders (government and communities) to develop skills and building an institution that can bridge migrants and stakeholders are still underdeveloped. Various constraints, ranged from the large number of migrants, voluntary absences, lack of material support, under-qualified teacher, limited business skill training, and limited networking are challenges that need to be addressed. In addition, vocational education/training curriculum are old fashioned and exclusive (segmented, only for active and bright worker). In the future development, it is vital to support more on communitybased education/training programs and open access to a life skill education (knowledge) that can increase the worker's self-esteem or self-transformation (a semblance of future carrier).
\end{abstract}

Keyword: migrants, capacity building, vocational education, empowerment.

\begin{abstract}
Abstrak
Pengamatan terhadap program pelatihan keterampilan pekerja migran Indonesia dan kegiatan pembelajaran berbasis komunitas di Taiwan, menunjukan peran: membantu pekerja migran membangun dan meningkatkan keterampilan berbisnis serta pengembangan kapasitas; memfasilitasi transfer pengetahuan dan menawarkan panduan tentang manajemen pengiriman uang yang produktif; dan juga mengembangkan komunikasi antar budaya dengan penduduk setempat. Namun demikian dukungan terhadap program pelatihan kejuruan dan pembelajaran untuk memperkuat migran menjadi berdaya sekaligus sebagai lembaga yang menjembatani migran dengan stakeholder tidak berkembang. Terdapat beberapa kendala yang dihadapi: jumlah pekerja migran yang membludak; ketidakpastian kehadiran; kesadaran diri untuk berkembang; tidak ada dukungan materi dari pemerintah; kualifikasi guru; keterbatasan program di wilayah perkotaan; jaringan sosial; dan kurikulum pengajaran hanya menyentuh sebagian kebutuhan pekerja migran dan eksklusif bagi pekerja yang mendapat libur kerja. Dalam upaya pengembangan pekerja migran, penting untuk memberi dukungan lebih banyak pada program pendidikan/pelatihan berbasis komunitas dan akses terbuka ke pendidikan kecakapan (pengetahuan) yang dapat meningkatkan kepercayaan dan transformasi diri pekerja migran.
\end{abstract}

Kata kunci: migran, pengembangan kapasitas, pendidikan kejuruan, pemberdayaan. 


\section{INTRODUCTION}

In the survey conducted by International Organization for Migration (2009) on Gender and Labor Migration in Asia, it was found that immigrant workers from Southeast Asia have some limitations, such as lack of skills, financial resources, networks, information, and education. For instance, Indonesian migrant workers in Taiwan are mostly employed in limited skilled jobs (or semi-skilled occupations), and low-paying jobs. The male workers mostly work in the agricultural sector and construction or manufacturing jobs, while a great majority of the female workers are domestic workers or caregivers (Mafruhah, et. al, 2012). Before their departure to the host country, they do not know the working conditions and situations there while during their time of working abroad, immigrants are often trapped in debt with their employment agencies (Lan, 2009). Migrant workers face difficulties such as long hours of work, communication issues, issues with the employer/employee's personal relationships, and no break during the holidays (Yuniarto, 2015a). Not only during their working period, when they return to their home country, migrant workers often find it difficult to invest their savings. If they choose to work behind the desk, only few local companies want to hire returned migrants who were domestic or factory workers because their skills are not that different from other workers (Bachtiar\&Prasetyo, 20I4). Migrant workers are also often lack the necessary qualifications for better jobs and they have limited knowledge of finances upon their return home (Yuniarto, 2018). Even when they possess some useful knowledge, returned migrant workers tend to not know how to use their knowledge to support their life in their home country. The problems before and after migration faced by Indonesian migrant workers are mostly because they lack knowledge and have limited skill for future carrier development (Randolp, 2015; Farbenblum et al., 20I8). Their low education is mostly the cause of the mistreatment they receive during their stay in the host country, especially toward the women (BNP2TKI, 20I6). Therefore, giving useful life skill education and training should be a strategic priority for the protection and empowerment of migrant workers. ${ }^{\mathrm{I}}$

Taiwan, in its capacity as a host country for migrant workers, has a number of skills and vocational training programs have been developed. These training programs include generic skills, such as language courses, culinary training, financial education, and finance management. Besides education, other activities including dedicated spaces for counselling; educational assistance, labor administrative help, and helping migrants in trouble. These education and training programs were set up by government institutions, trade unions, and private educational and training institutions. The purpose of these training programs is to prepare migrant workers for the tasks and functions that are expected of them in their host countries, to develop communications skill with employees and local residents, and to impart knowledge and prepare migrant workers when they return to their hometown. There are also some informal education activities where a migrant group or associations help the workers develop new skills. For instance, at Taipei Main Station (TMS), some migrant NGOs actively hold Mandarin language classes every week, as well as other courses, such as finance management, health reproduction course, English class, and counselling. Around the TMS, a group of Indonesian community have makeup and hairdo courses that are held every three months for female migrant workers living around Taipei. Every Sunday at the South Exit of the TMS, the school created by Indonesian and Taiwan worker associations and Indonesian religious association organize free mandarin and business-management classes, which help with worker's everyday life and monthly religious events to promote

\footnotetext{
I According to the new regulation Indonesian Integrated Services and Protection of Indonesian Labour Migrant, Law Number 18 Year 2017, article no. 6 on education point, said that every migrant worker (including candidate) has the right: 1) gain increased access self-capacity through education and job training; 2) obtain information right about the job market, procedures for placement, and conditions work abroad (Ghofar, 2019). This law give mandate to government and society in developing migrant labour knowledge and capacity building for work and while they return.
} 
socialization between Indonesian workers and Taiwanese. Still around TMS, there is a Community Reading Park where the workers can read various books - including health dictionaries, contemporary women's fiqh (theory of Islamic law) and marriage books, and constitutional law book - freely provided.

As vocational training and communitybased education adapt to workers condition and facilitate migrant needs continues to grow, this paper ask the question: what constraints and which conditions of the vocational training and migrant community learnings are most significant or influential in determining or inhibit worker's capacity building and protection? This paper aims to show how migrant workers education, as seen in Taiwan, play an important role in reinforcing the situation among workers that knowledge is real work, can improve skills and working conditions, satisfaction in life, and improving their life.

\section{METHOD}

The data collection and categorization of this study was limited to the three NGOs working on the issue of migrant workers education, which are One-Forty, Global Worker Organization, and Community Learning Center Bhakti Jaya; the programs by Indonesian representative government (KDEI) and Association of Taiwanese Neighborhood Community Service; and three Indonesian migrant community in Taiwan i.e. Nahdatul Ulama branch in Taiwan (PCI NU), Indonesia Suara (Indosuara), and Indonesian Worker Association in Taiwan (IPIT). These organizations were chosen because they are outstanding migrant worker communities that deal with worker's education. By comparison, government vocational programs were also observed because they held routine activities on entrepreneurship training and financial management training to improve migrant worker's skills. Relying mainly on interviews conducted with members of the groups' staff members, this study developed ethnographic explanation on migrant workers and the issues they faced to get education in Taiwan. This study used a qualitative research, having gathered the primary data through in-depth interviews and participation observation on education and migrant community activities. The fieldwork was conducted from April to August 2019, with Taipei City and Taoyuan County as the research locations. Most interviews were conducted on weekend, since many migrant workers have their day off on the weekend and it was when they can attend the training and courses. Secondary data was also collected from library research. This paper is divided into several parts. First, an explanation on how Indonesia migrant worker lack the necessary knowledge before they depart to the host country where they work. Second, a brief description on current Indonesian workers' situation and condition in Taiwan. Third, explanation of migrant worker community learning as a place for migrant workers to socialize and learn new skills. Fourth, the significant knowledge from vocational and training programs taught to migrant workers. Fifth, the constrains from migrant workers in developing future carrier due to their limited education. And sixth, the effect of vocational education and training on migrant protection issue and capacity building.

\section{LITERATURE REVIEW}

Several articles mentioned the important of migrant workers capacity building and the role of vocational education and training (VET) programs. Tayah (20I6) said skills development programs for migrant workers play an important role in reinforcing the view among workers and employers that domestic or factory work is real work, improving working conditions, employers' satisfaction, and empowering migrant workers. OECD/ILO (20I7) in their research conclude that VET can improve the quality of the match of foreign workers in three ways: contribute to strengthening foreign worker social capital; function as screening agencies for prospective employers; and improving labormarket efficiency. Migrant community-based education (including knowledge sharing) can have positive social externalities modifying the migrant worker at society level: it contributes to social capital as well as human capital (ILO, 20I8). The impact of community-based education for migrant capacity building have 
been conducted. Chang et al. (2012) found that a community-based education process that integrated popular education and community organizing components allowed for training participants to identify the problems they face in their current situation. Education contributes to better health, higher life expectancy, lower crime, better parenting, better governance, enhanced trust, etc. (ADB et al, 2015). The role of education in increasing returned migrant economy is also found. Yuniarto (20I6a) describes vocational training by Indonesian government to promote entrepreneurship for returned migrant can develop future carrier rather than remigration. Meanwhile, the VET effectiveness in improving foreign worker labour-market outcomes could be limited when foreign workers refuse to enroll in VET or to get in contact with VET providers (Cedefop, 20II).

Wagemakers, et al. (2015) said that the 'point of entry' into a migrant community education can be effectively made through community-based organizations, a mechanism that has been used by government and nongovernment programs to develop migrant capacity building. The involvement of the social partners in successful migrant community education programs means that institutions have ready access to firms' migrant skills needs and to the supply of skills (Cedefop, 20Io). For instance, in Taiwan, government and NGOs become social agents who organize cultural, financial, social, and human capital to generate revenue from activities held for migrant workers (Tsai \& Hsiao, 2007). In Taiwan, the government or NGOs involved in migrant issues held social activities that are usually linked with a social and cultural element (i.e. education, organizing cultural activities, problems solving training, etc.), and they consist of pursuing innovative solutions to social problems and serve to build solidarity within the communities (Lin, 20I7). On the contrary, Indonesian Law No I8/2017, states that in undertaking education and training for workers, the government can include recruitment agencies, other organizations, and/ or the community. However, the government has failed to monitor whether the workers have received adequate education or training (Syaiful,
2009). State institutions in charge in migration and migrant worker placement companies (Perusahaan Jasa Tenaga Kerja Indonesia/ PJTKI) are not well-prepare to hold education and training for prospective migrant workers without monitoring and evaluation processes (Susilo, 2010).

\section{FINDINGS (NO) PRE-DEPARTURE TRAINING}

Pre-departure orientation programs have emerged as an important tool for the protection of migrant workers, especially when abroad. Indonesia's Migrant Worker Placement and Protection Law of 2017 mandates all emigrant workers to complete the Final Pre-Departure Briefing (Pembekalan Akhir Pemberangkatan, PAP). The Length of the program is only 8 hours. The program is initiated by BNP2TKI (National Agency for Placement and Protection of Indonesian Migrant Workers). According to Mr. Pangkuh, the PAP instructor, ${ }^{2}$ the PAP program focuses on laws and regulations in Taiwan, depending on the employment agency system and the employer culture. The briefing covers the following topics in four two-hour sessions: (I) working conditions, regulations and laws, culture and customs of destination countries, and return procedures; (2) employment contracts (covering pay, insurance, and the overseas worker ID card); (3) mental and psychological concerns and personality (including tips on ways to be assertive and develop a positive attitude); and (4) drugs, sexually transmitted diseases, HIV/AIDS, and illegal trafficking. In a final statement, the instructor provides a general message on becoming a good worker, being careful abroad, saving money, and how to successfully return home. Parenas et al. (2018) observed, in training sessions for domestic workers bound to the Middle East, the governments of Indonesia warn prospective migrants of the risks of physical and sexual violence, the likelihood of overwork, the possible absence of a day off, the denial of the use of the Internet and telephone, and the possibility they would not be able to stomach the foods provided by employers. 
Beside PAP, there are the skills improving program by recruitment agencies. Elaborated in the Regulation of BNP2TKI Head No. I of 2017 on Implementation Guideline of Skills Upgrading Training for Prospective Migrant Workers, the program offers contracts to training institutions to enhance the capacity of the prospective workers whose competencies do not meet employers' requirements. The skills upgrading program is conducted prior to departure. It targets those with elementary or junior high school degrees and with work contracts in-hand. Moreover, the work contract should be with non-household employers. Article No. I of the Upgrading Skill Regulation says that the program is to prepare qualified workers to achieve level of competence that meet requirements of the overseas users. Meanwhile, workers with contract in-hand have, indeed, met the requirements. Thus, the program claims to be skill upgrading program, but it also operates as skill enhancing program.

However, it is unclear whether migrant workers actually acquire the necessary and relevant information from these pre-departure orientation programs. One of the study's informants was Minem, ${ }^{3}$ a migrant worker from East Java, who shared her experience when preparing her departure for Taiwan. She said that the financial education, self-employment or life-skill improvement topics were more interesting than the briefing gives, which limit the introduction or explanation from the textbook. Minem explained:

For a new migrant worker, the PAP briefing is important, but I already know it as I have worked in Taiwan three times [contract-based], while for others it might be their first or second time working abroad. In my opinion, teaching how to access bank credit, venture capital, business development, or small-scale entrepreneurship for migrant workers is more important. Financial education or self-employment topics are mentioned, but not in detail. During the PAP discussions about business experiences, we exchanged [information] with other workers who we met.

The migration backgrounds and experiences of migrant workers are diverse (first

3 Interview with Minem, Taipei, April 2019. timers vs. rehires, long-term migrant workers, returning migrant workers and so on). Predeparture information programs tend to have a one-size-fits-all design. In Minem's case, financial education or self-employment topics are more important than other topics, such as administrative or topic on preventing problems while abroad. Migrant workers similar as Minem are skeptical about the value of the materials discussed in the training. In practice, working abroad depends on the employment agency and the employer, but when dispute between employer and employee occur, the state and migrant agencies are not responsible. To settle the disputes between workers and employer, the agencies and employers should also be educated and trained, not only the migrant workers. Migrants work overseas for money. However, workers, especially women, are not always in control of their earnings, and many do not make wise financial decisions to save, invest, or create a business to sustain their families at home and prevent the need to re-migrate. Therefore, financial literacy training on a pre-departure training program should be developed. This training will improve how migrant workers and their family spend the money they earn. Therefore, involving civil society organizations in training programs for migrant workers is significant. Migrant NGOs should also develop training materials, resources and strategies to help organize campaigns to raise awareness to such problems and to educate migrant workers before they depart to their host country.

\section{INDONESIAN WORKERS SITUATED IN TAIWAN}

According to the National Immigration Agency, Taiwan housed more than 700,000 migrant workers in 2018, with Indonesian migrant workers being the most common there $(268,576)$, followed by Vietnamese workers (223,300), the Philippines (154,209), and the Thais $(60,764)$. The majority of migrant workers, amounted to $60.43 \%$, works in manufacturing jobs, with domestic helpers and caregivers placed second, comprising $36.71 \%$ of the total migrant workers, while the agricultural, forestry, fisheries and husbandry sectors (domestic and international 
sailors) amounted to I.82\%. Meanwhile, workers who work in major investment, construction engineering and other public works are about I.54\% (Everington, 2019). In general, migrant workers in Taiwan are visible but their existence are not recognized (Lovebland, 2009). They are regarded as the 'undesirable others' on the opposite side of the boundary of modernity, civilization and prosperity, the key components of Taiwan's self-identity (Cheng \& Momesso, 2017). They are excluded from the welfare programs for which they are mostly working, are banned from permanent visas or naturalization, and are prohibited from being joined by family members (Lopega, 20I7). When migrant workers came to Taiwan, they bring different culture, their existence are also excluded (Huey-jen, 2007). These 'new taikers' are thus 'stigmatized' or rendered 'invisible' by Taiwanese society (Tierney, 2008). Related to their education, compared to Filipino, Thai, or Vietnamese migrants, Indonesian factory worker, fisher, and caregivers are still far from qualified. For instance, Filipino workers must at least finish their diplomas, while the Vietnamese workers receive training before they can work in Taiwan. Thai migrants are already specified as factory or construction workers; hence they are quicker to adapt. Meanwhile, Indonesian workers, as this study observed, are mostly only graduated from elementary school; they are learning by doing and have limited knowledge of work regulations and conditions. ${ }^{4}$

This study observed, most Indonesian women workers in Taiwan are employed as domestic workers, or in some cases as nurses or caregiver. Being a nurse or a caregiver and being a domestic worker is the most popular employment option for women migrants for many reasons. Usually the salary is higher than they are paid in Indonesia. They only have primary or junior high school diploma and domestic work does not require higher education. Domestic work often requires tasks they are already familiar with such as housekeeping and caring for young children or the elderly. However, Taiwanese regulation does not allow domestic

4 Interview with Zainal (male, 61, ex-migrant worker), Kaoshiung. August 2019 workers to have holidays off. Meanwhile, factory workers can leave for holidays (around 8 a.m.); by Io p.m. they are expected to be back to their dormitories. Domestic workers are to be back home before dinner (7 p.m. to Io p.m.). Because of the short time available, free time must be spent efficiently on Saturday and Sunday, despite the multitude of tasks and responsibilities (going to church or mosque, getting a haircut, shopping, eating, and socializing) (Huang \& Douglas, 2008). Unfortunately, migrant workers spend their time with friends at the corners of the train stations, eating and dancing behind the prime public areas of Taipei, Taoyuan, Zhongli, and Taichung stations, and they tend to shop underground rather than in skyscraper department stores. They prefer Indonesian shops, night markets, as well as stores that sell commodities from their homeland (Hung Cheng, 2014; Lan, 2003).

These condition gives us an understanding about Indonesian migrant workers characteristic and situation in Taiwan. As a respond to their conditions, migrants try to escape from marginal position by socializing with friends and migrant associations as adjustment process under minority (Yuniarto, 2015b). These situations are a part of self/group expression and adaptation in Taiwan. For instance, every Sunday, Indonesian migrant workers usually gather among themselves in their special space (neighborhood shop). In these meetings, they share their feelings of homesickness and seek emotional release. They talk to each other about their difficulties working in Taiwan. They help each other and help newcomers by sharing their experiences. They live far from their country and their families, and they live in a strange environment. According to Widyowati (20I4), migrants face numerous difficulties, especially those who came to Taiwan with little grasp of the Chinese language and cultural differences. Most of their lives are filled with difficult things, so they need to share and socialize.

\section{COMMUNITY LEARNING}

Among Indonesians in Taiwan, there is formation of migrant group associations. The existence of Indonesian migrant associations 
in Taiwan has grown rapidly since $2010 .{ }^{5}$ These groups exist to provide migrants with a place to express their creativity, education, to forge solidarity, to impart a sense of freedom of expression, and to create positive activities. One of most prominent organizations is the Nahdlatul Ulama (NU) ${ }^{6}$ branch in Taiwan that tries to assist Indonesian migrant workers, especially Muslim, who encounter difficulties. According to Didik, a PCI NU secretary general, a common problem for recent arrivals is their inability to communicate what they need and what they want with employers because of their lack of Chinese language skills. When employment agencies are too busy, or unwilling, to deal with these situations, the NU branch can provide needed assistance. In some cases, the passports of migrant workers have expired and they don't want to spend extra money on renewing them through their employment agent; or they plan to give up their job in Taiwan and return home early. They often turn to NU to learn about passport renewal procedures and the relevant procedures of Taiwan's $\mathrm{Na}$ tional Immigration Agency, or to book a ticket to Indonesia. In each of NU's Taiwan branch offices (Taipei, Taichung, Changhua, Douliu (Yunlin), Donggang (Pingtung), and Magong (Penghu), there are two or three volunteers

\footnotetext{
5 Interview with Kadir, a KDEI staff. Taipei. May 2019. According to him, recently there morethan 80 Indonesian migrant association formed in Taiwan, among others Madiun People in Taiwan (Wong Madiun di Taiwan, WMT), Magelang Boy (Bocah Magelang), Indonesia Taiwan Art Culture Community (Paguyuban Seni Budaya Indonesia Taiwan), One Heart Fraternity (Persaudaraan Setia Hati), North Java Community (Komunitas Pantura), Sumatra Man (Lintas Sumatra), West Java Group (Viking Persib), East Java Group (Pasopati), Indonesia Seafaring Family Forum (Forum Keluarga Pelayaran Indonesia Taiwan), and the Indonesia Hsincu Community (Forum Silahturahmi Indonesia Hsincu). There are also Indonesian religious organisations, mostly Muslim, such as the Banyuwangi communities (Ikatan Warga Banyuwangi, IKAWANGI), Indramayu Muslim communities (Ikatan Muslim Dharma Ayu Taiwan, IMDAT), Majelis Ta'lim Yasin Taipei (MTYT), Forum Silaturrahim Muslim Indonesia Taiwan (FOSMIT), Ikatan Muslim Indonesia Taiwan (IMIT), Majelis Ta'lim Yasin Chiayi-Indonesia Taiwan (MTYC-IT), Ikatan Warga Muslim Indonesia Taiwan (IWAMIT), Indonesia Muslim Family in Taiwan (Keluarga Muslim Indonesia Taiwan, KMIT) and Indonesian Muslim On Air Community in Taiwan (Komunitas On Air Muslim Indonesia Taiwan, KOMIT).
}

who are working to improve Muslim women's lives and offering information on legal issues. In Taipei, for example, the NU facility is used to host religious activities, but it also includes a small basement classroom used for educational programs. The programs offered every Sunday are not only language classes, but also courses to improve workers' skills on practical subjects such as sewing and makeup. As for learning English and computer classes, this organization invite NU member who are college students in Taiwan to teach the workers." 7

Organization that are actively giving out community learning programs are not only religious organizations. The observation found that Indonesian entrepreneurs in Taiwan are also active in helping the education of unskilled migrant workers. Beyond their entrepreneurial activities is their role in social activities. Their interpersonal and social relationship are based on non-economic transaction. As demonstrated by their business orientation, rather than merely providing migrant workers with local products and migrants need services for co-ethnic market (such as spaces for socio-religious practices, entertainment, sending money, and communication media with their family); entrepreneurs' also provide 'social services', such as dedicated spaces for counselling, educational assistance, labor administrative help, and helping workers who face difficulties during their stay. These non-economic practices are referred to as social activism, patronage, and broker agency of Indonesian migrant entrepreneurs in Taiwan (Yuniarto, 20I6b). These types of activities go far beyond economic business practices in combining and manipulating their entrepreneur status and position (as middleperson) adjusting to labor conditions and develop certain social relationships among their co-migrants.

One of Indonesian entrepreneur organizations that exist to develop vocational training for unskilled migrant workers is Indosuara (Indonesia Suara/Indonesian Voice). Indosuara helps migrant workers connect with each other and share information regarding health reproduction training, business (entrepreneur-

7 Interview with Didik, Taipei, May 2019 
ship) classes, and financial management. Since 20Io, Indosuara has held social activities, such as entrepreneurship and investment seminars, health workshops for migrant workers, language training, travelling in Taiwan, holiday parties, and collecting donations for migrant workers in difficulty, all catering to the needs of migrant workers. Mr. Simson, the leader of Indosuara, said, "We invite the migrants to take tours around Taiwan. For example, to visit the Taiwan National Museum, visit heritage sites, hiking and enjoying natural scenery, taking a bike tour, or participate in a music festival or short story writing competition. For me, this relationship with migrant worker become a further effort to support worker's creativity and self-actualization." These activities that are routinely held each month aim to empower migrant workers and develop their skills. ${ }^{8}$

According to Ms. Mira (female, Indosuara staff), until 20I5, there is no support, no regulations, funds, or organizations, both from the Indonesian or Taiwanese government or other organization to help or improve the migrant workers conditions. ${ }^{9}$ Seeing this, Indosuara Company took the initiative to help migrant workers in Taiwan. Working together with the migrant NGO Indonesian Migrant Worker Association in Taiwan, at first Indosuara handled Indonesian migrant cases, such as fixing salary deductions by agencies, visiting employers of underpaid migrant workers, asking agencies to give their employees their personal identity documents, donating food and money to migrant workers in need, and sending letters to the Indonesian government in Taipei regarding workers conditions. Moreover, Indosuara published online magazine to inform migrants of anything related to the trends around migrant workers issues, such as activities they can take part in, news, conflicts, and stories. Indosuara built solidarity among Indonesian migrant workers who visit their headquarter so they can find strength in togetherness and help each other.

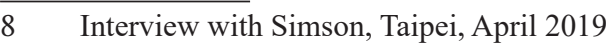

9 Interview with Mira, Taipei, July 2019

\section{VOCATIONAL EDUCATION/ TRAINING (VET)}

Migrant VET program has not been developed for a long time in Taiwan. However, the development of this program grew rapidly along with the growth of migrant NGOs since 2005 that, in its development, become key players, in providing training programs and community building among migrant workers. This trend happened in Taiwan prior to the New Southbound Policy initiated by Hope Workers' Center (established in I986) and was continued by the establishment of various migrant workforce associations, such as Taiwan International Workers Association (TIWA, established in I999), Haohao Women's Foundation (established in 2008), Global Worker Organization Taiwan (established in 2013), One-Forty (established in 2015), and others. The organizations are offering variety services to migrant workers, most often assisting in cases of unpaid overtime and human trafficking. They also offer skills development classes to the Southeast Asian migrant workers; it went on to employ some of the class attendees as social workers to provide services to migrant workers.

The VET organization in Taiwan plays a key part by deliberating on empowering migrant workers and developing their entrepreneurial skills in weekend and monthly trainings specifically offered to migrant workers. VET programs supported by Indonesian representative office and migrant NGOs offered entrepreneurial seminars and training programs on business management, business skills, and product implementation. An aspect of these governmental and NGO activities was education on financial management to empower low-skilled Indonesian workers and help them to wisely use their incomes. Besides, VET institution provides migrant workers in Taiwan with practical information's and services about work, everyday live, lifelong learning and cultural exchange, and protecting their rights trough local care and support. These activities promote their social inclusion and facilitate cross-cultural exchanges and understanding. 
According to Mr. Fadjar, head of KDEl's labor division, VET programs aim to spread an entrepreneurial spirit, change the work paradigm, and develop the creativity of Indonesian workers. The ultimate goal for future migrant workers includes entrepreneurial knowledge and diversified expertise that could ultimately be developed in the home village. "With this training, the government hopes that after work in Taiwan, migrant workers will have the ability to seek new alternative livelihoods at home," stating the head of KDEl's labor division. Through the programs held, migrant workers' wish after returning home at the end of their contracts, they could still prove valuable in improving Taiwan's business links with their countries. With their language skills, they could offer immediate assistance to local businesses in this field. ${ }^{\text {Io }}$
In practice, both NGOs or government representative office joint together with schools or universities to offer professional and vocational training programs to help migrant workers cultivate skills that can be used to find jobs or start their own businesses when they return home. This has become an important networking of the cooperation between the academia, vocational education institution, and the local government representative office. According to Fadjar, due to underqualified teacher/lecturer, the vocational education activities in Taiwan was inseparable from the roles of university students, migrant organization, and government representative who have capabilities to teach migrant workers. The figure below shows profiles and examples of education activities for Indonesian migrant workers in Taiwan.

Table I. Profile of VET Organizations and Programs in Taiwan

\begin{tabular}{|c|c|c|}
\hline No & Institution & Program Descriptions \\
\hline 1 & $\begin{array}{l}\text { One-Forty: } \\
\text { Make Every Mi- } \\
\text { grant Worker's } \\
\text { Journey Worthy } \\
\text { and Inspiring }\end{array}$ & $\begin{array}{l}\text { One-Forty provides online and offline learning platforms for migrant workers in Taiwan, and be- } \\
\text { lieves capacity-building is an important dimension of their lives after work. The One-Forty School } \\
\text { holds classes teaching SEA migrant workers skills that they need for a steady career in either } \\
\text { Taiwan or their home country; fixed classes include basic Chinese class, advanced Chinese class } \\
\text { and business courses. The Chinese classes start with listening and speaking, and then move to } \\
\text { reading and writing. Recently, One-Forty has also opened experimental classes such as computer } \\
\text { class and cosmetics class. In addition to classes, One-Forty holds the event Open Sunday once } \\
\text { a month. Open Sunday not only lets the migrant workers enjoy some leisure time, but creates a } \\
\text { "bond" between migrant workers and locals. This cultural event is usually based around a cook- } \\
\text { ing party theme, inviting migrant workers to teach participants to cook the traditional delicacies } \\
\text { of their hometown, or going on a one-day trip to make fond memories of their time here. One- } \\
\text { Forty's website also features Migrant Life Channel, which gives voice to migrant stories. Here SEA } \\
\text { migrant workers share their experience before, during and after migration. }\end{array}$ \\
\hline 2 & $\begin{array}{l}\text { CLC Bhakti } \\
\text { Jaya: One-stop } \\
\text { school (books, } \\
\text { knowledge, } \\
\text { and skills) }\end{array}$ & $\begin{array}{l}\text { Community Learning Center - Bhakti Jaya Indonesia (CLC BJI) operating an Equality Education in } \\
\text { Taiwan since 2013. CLC BJI is currently engaged in } 3 \text { main areas of education, namely: } 1 \text { ) Equality } \\
\text { Education (Pendidikan Kesetaraan) consists of three package: Package A (Elementary School); } \\
\text { Package B (Middle School); and Package C (High School); } 2 \text { ) The Taiwan Community Reading Park } \\
\text { (Knowledge House), to encourage reading interest of migrant workers and support the local } \\
\text { reading movement; and 3) Skills Course, the programs include Mandarin language and women } \\
\text { beauty course. Besides intra curriculum, CLC BJI also held direct outreach to migrant worker. For } \\
\text { instance, in a corner of Taipei Main Station, there are Indonesian-language books - including } \\
\text { health dictionaries, contemporary women's figh (theory of Islamic law) and marriage books, and } \\
\text { a long constitutional law book - made available with the words "Read For Free" displayed on a } \\
\text { sign. This program was launched in } 2015 \text { CLC BJI. }\end{array}$ \\
\hline
\end{tabular}

Io Interview with Fadjar, Taipei. August 2019 


\begin{tabular}{|c|c|c|}
\hline No & Institution & Program Descriptions \\
\hline 3 & $\begin{array}{l}\text { Global Workers } \\
\text { Organization } \\
\text { (GWO): Noth- } \\
\text { ing about us } \\
\text { without us }\end{array}$ & $\begin{array}{l}\text { GWO is a non-profit organization established in 2013, formerly known as "Taiwan Foreign Work- } \\
\text { ers Development Association". Based in Taipei, this NGOs provide migrant workers in Taiwan with } \\
\text { practical information's and services about work, daily life, lifelong learning and cultural exchange, } \\
\text { protecting rights trough local care and support. They also promote social inclusion and facilitate } \\
\text { cross-cultural exchanges and understanding. The Global Workers' Upskill Centre, which is a joint } \\
\text { collaboration between Global Workers' Organization (GWO) and KaiNan High School of Com- } \\
\text { merce and Industry, started to offer training in e-commerce and home baking every Sunday for } \\
\text { migrant workers to expand their personal skills and improve employment opportunities. After } \\
10 \text { weeks of training, they will receive a certificate for completing the training, GWO spokesmen } \\
\text { added. The classes are currently available only to Indonesian workers and expected to open for } \\
\text { Filipinos and Vietnamese migrant workers in the near future, especially those who are due to } \\
\text { return to their home country soon. }\end{array}$ \\
\hline 4 & $\begin{array}{l}\text { Indonesian } \\
\text { Economic and } \\
\text { Trade Office in } \\
\text { Taipei (KDEI): } \\
\text { Exit Program }\end{array}$ & $\begin{array}{l}\text { Entrepreneurial training, referred to as the "exit program" for Indonesian workers in Taiwan, was } \\
\text { created in } 2012 \text { by the KDEl office. The Indonesian government offered entrepreneurial seminars } \\
\text { and training programs that disseminated information on business management, business skills, } \\
\text { and product implementation. Invited speakers give lecture in the seminars and trainings who } \\
\text { ranged from students and experts to successful migrants and entrepreneurial agents. Participants } \\
\text { were educated on business, focusing on preparing for financial self-sufficiency after working } \\
\text { overseas. }\end{array}$ \\
\hline 5 & $\begin{array}{l}\text { Taiwan Local } \\
\text { Government: } \\
\text { Integrated and } \\
\text { Multicultural }\end{array}$ & $\begin{array}{l}\text { In Taipei New City, Taoyuan, and Taichung government held free Chinese language program } \\
\text { designed for migrant workers to help them assimilate more quickly into society. The program was } \\
\text { first initiated in 2016, and after a one-year hiatus in 2017, it resumed in 2018. The classes usually } \\
\text { begin on July and will be split into four sections catering to Indonesian, Vietnamese, Filipino } \\
\text { and Thai workers. The classes are grouped based on nationality because they rely on bilingual } \\
\text { instructors who use their native tongue to help teach the course material. There will be about } \\
30 \text { students in each class, which will involve phonetic symbols, communication and dialogue, } \\
\text { reading, and learning by singing. By offering Chinese classes to foreign workers free of charge, } \\
\text { the program hopes to minimize language barriers and give the workers an in-depth understand- } \\
\text { ing of local Taiwanese customs and living habits. Migrant worker students should not be afraid of } \\
\text { joining the classes if they don't know the language well at first and look forward to the benefits it } \\
\text { will bring afterwards. }\end{array}$ \\
\hline
\end{tabular}

Source: Data compilation, Rudolf, fieldwork 2019.

Figure I. Migrant workers vocational education and training for Indonesian in Taiwan
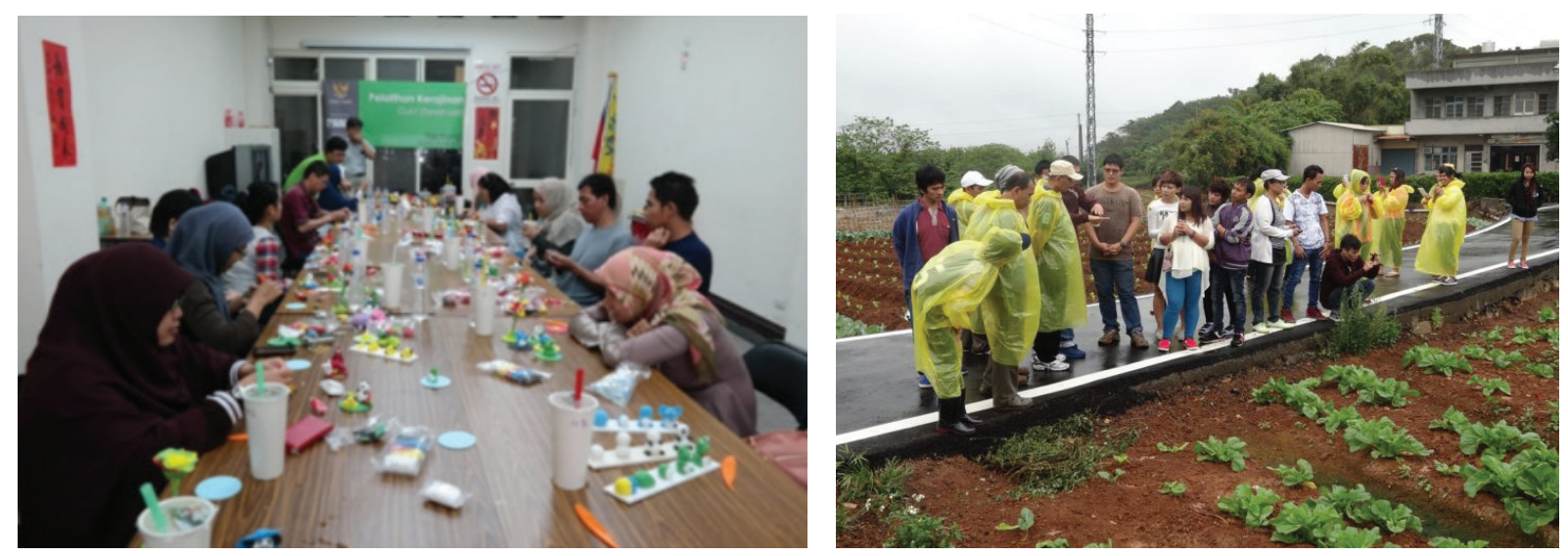

Art clay training (left) and vegetable farm training (right) by KDEI

Source: KDEI, 2016. 

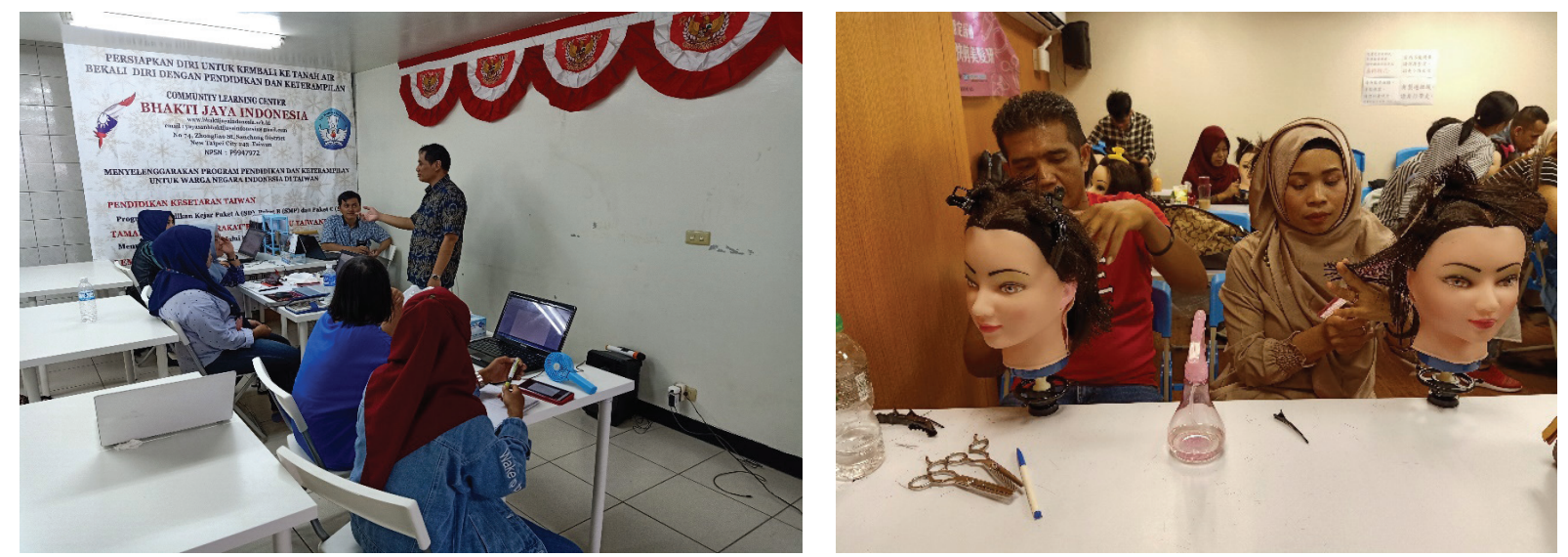

Entrepreneurship training by Bhakti Jaya Indonesia (left) and hair salon training by GWO Taiwan (right),

Source: Rudolf, fieldwork, 20I9.

\section{THE EFFECTS}

Fidati (female, 30,) is a migrant worker who took clay sculpting courses in KDEI exit training programs. After continuously practicing for more than six months, she could achieve two intermediate certificates in clay work. She said, "I want to open a clay doll business after returning to Indonesia later." She told me that she was hoping to continue to practice clay sculpting in the future. In addition, she stated, "Instead of hanging out without purpose on the weekend, obviously, I would rather spend my time training in a clay course. This training will become my provision in Indonesia later in order to open the clay business. To be sure, I must first collect money and improve my skills." Migrant community learning and VET programs are significant experience for Indonesian workers in Taiwan because they provide spaces for public dialogue and the opportunities for workers to express their concerns. The experience makes workers more confident about their condition while working abroad and can benefit them when they return home. Fidati's experience illustrates how the trainings influences migrant workers transformations. ${ }^{\text {II }}$

On the other hand, Indonesian workers productively use their free time to establish social networks with other Indonesian immigrants in Taiwan that seamlessly translate into social relationships. Yuhalini (female, age

II Interview with Fidati, Taipei, June 2019.
26, a member of IPIT) and Cindy (female, age 32, a member of Indonesian Muslim Community in Taiwan) are two domestic workers who reportedly gained support from their friends and organizations for their efforts to reach and develop their personal potentials and employment independence. They explained that their friends and organizations taught them how to utilize technology, such as using laptops and the Internet, and facilitated their learning by giving them free used laptops. The organization where Yuhalini is a member is an Indonesian migrant association that fight against the marginalization of migrant workers, and Cindy's organization is a Muslim community that help workers in need. Through their organizations, Yuhalini was inspired to be a writer and Cindy was encouraged to become a Muslim cloth trader in Taiwan. Since August 2014, Yuhalini has published more than 15 short stories in a local magazine and portions of a novel anthology. Over the past three years, Cindy has been running an online store business network. Both of them learned business management while they were in working. ${ }^{\text {I2 }}$

The effect of vocational training and community learning on capacity building can be seen in the case of migrant workers who came back to their village. Fieldwork observation done to returned migrant workers found that increased self-confidence, assertiveness, and

I2 Interview with Yuhalini and Cindy, Taipei. July-August 2019. 
self-reliance were generally the prominent effects of these programs, particularly among successful returned migrants who were able to establish their own livelihood. A former migrant worker in Taiwan, Meiske, (age 40, East Java, salon /bridal makeup artist) said: "Even though I worked as a domestic helper overseas, I have many friends and was active in the migrant workers organization. I became more confident upon my return, and no longer work on farmland but prefer to start my own salon business as I have a talent in it and I am interested in it." Meiske worked for twelve years as a housekeeper in Taiwan. Now, she rents a traditional Javanese wedding gown to residents and become a marriage make-up stylist. She employs family members to help with her business operations and is able to finance the establishment of her son's sound and music rental business. Moreover, she is able to give some of her profits to purchase a business car for her husband. With her business, she is her family's breadwinner. With her role switch in the family and her ability to explore her own potential, she is better equipped to face the future. She has become empowered with the realization that it is possible for her and her family to live better. Her transformation is an eloquent testimony of what could be achieved through vocational training and community learning. ${ }^{13}$

Another example, Henny (female, 30, just finished her contract and is back in Indonesia), while she was a domestic worker in Taipei, she engaged with the Indonesian community in Taiwan through the Majelis Ta'lim Yasin Taipei (Indonesian Muslim Group in Taipei, MTYT), a part of the PCI NU in Taiwan. There, she learned how to be a good worker and gained knowledge and motivation to better manage the money that she earned for more productive activities. At her organization, she often took part in discussions about self-development during the religious lectures that the organization provided. When she returned home, she established a small grocery store and developed her business using a door-to-door selling service as a business model. She applied the knowledge

I3 Interview with Meiske, Taipei. May 2019. and strategies she obtained in Taiwan in her village and modified it according to the financial situations of her fellow villagers. ${ }^{14}$

These examples of how migrant workers benefit from the learning process illustrate how acquiring entrepreneurship knowledge is similar to the process of becoming familiar with a new culture. In addition, they actively used social media to promote their businesses. They said that their experiences could be applied in Indonesia (in their home villages) by adapting them to local characteristics, such as the villagers' extent of purchasing power and regional business trends. They pointed out that they had obtained more relevant knowledge from their immigration experiences than they were before their work abroad. These skills and experiences position them to successfully establish businesses when they return home.

VET and community-based learning as already mentioned above, can improve economic wellbeing as well as protect migrant workers from bad working condition, provide workers with a place to express their creativity, to broaden their knowledge, to build friendship, to impart a sense of freedom of expression, and to be involved in positive activities. For instance, GWO and One-Forty have a purpose to make migrant workers easily integrate to Taiwan society through communication (language) skill. Even though it is a very difficult task, but it needs to be done because Taiwan needs labor force and need to communicate with them. The locals in Taiwan still have many negative stereotypes about migrant workers from Southeast Asia. Thus, migrant workers in Taiwan are difficult to integrate into Taiwanese social culture due to the lack of communication means and information caused by language barrier. Fortunately, the Taiwan government sees this problem and the role of NGOs such as GWO and One-Forty become apparent. The GWO and One-Forty is a bridge that connects migrant workers and the locals of Taiwan. They try to integrate the social life of migrant workers in Taiwanese daily life. To them, working abroad is the path people dare to take in order

I4 Interview with Henny, Taipei. May 2019. 
to achieve their dreams and an innovation for transnational solidarity.

The government and NGOs usually combine these activities, which then become the foundation of an emergent bond of solidarity that promotes humanity values throughout the Indonesian migrant community. This in-group feeling of solidarity has the potential to explore how migrant interact and, in this case, Indonesian migrant communities and Government and NGOs social relationships come into existence. By performing these roles, Government and NGOs vocational training become one of the most significant factors that influence the improvement of migrant conditions and promoting social adjustment processes in the Taiwanese migration situation and at home. The immediate effect of this training and community learning are a form of solidarity among workers and protection of Indonesian migrants in Taiwan from difficulties in life and work. Social solidarity, rather than being simply defined as a group networking, forms the basis for long-term relationship and togetherness. In addition, the trainings from the government and NGOs provide social services and perform social transactions migrants with different background, such as spaces for religious worship, education, entertainment, administrative help, and dedicated spaces for counselling and other facilities. The vocational education and training institution play a key part by empowering migrant workers and developing their entrepreneurial skills on weekend and monthly trainings specifically offered to migrant workers. Beyond their institutional acts is their social role, interpersonal and social relationship to be based on mutual transaction.

\section{SOME CONSTRAINTS}

Despite the benefits obtained from these programs, the largest obstacle to the programs' success was the small numbers of participants. The small numbers of female participants is due to the fact that female workers (hospital nurses, domestic helpers and nurses) have no time off because their jobs are "on-demand services". Meanwhile, male factory workers who have more opportunity to spend their free time on the weekend compared to domestic workers may not participated because the training programs are mostly intended for the female workers, except language and computer training, such as hair-do and make-up training, health and nutrition classes, or baking. Male workers prefer trainings that they can apply at home such as carpentry, farming, fishing, trades, or e-commerce. Almost all programs held by the organizations are similar. This condition causes the trainings become monotonous. After all, the workers received training only once at the beginning of the project and after that, they have had no other opportunities to further improve their skills.

According to Dewi, a CLC-BJI staff member, the difficulties of running a community learning lies in the tendency of Indonesian migrant workers to play on their mobile phones and hang out with their friends rather than studying or reading. Their living and working conditions contribute highly to this attitude. They live far from their country and their families and they live in a strange environment. They face numerous difficulties, especially workers who came to Taiwan with little grasp of the Chinese language and cultural differences. Therefore, the workers prefer to hang out among themselves in the neighborhood shops around the railway stations. ${ }^{15}$ The study also found out that planning ahead is an issue faced by migrant workers when their employment ended and how they have difficulties to cope with conditions in their home village when they return. They expressed a desire to return to their hometown and they want to have a job with reasonable income. It seems that opening a business in their hometown was a priority of the immigrants' future financial plans. However, when asked about concrete business plans, they tended to be vague, ambiguous, and somewhat uncertain in their answers. In fact, the conditions in which the immigrant workers lived fundamentally influenced the likelihood of entrepreneurial activities after returning home. Lack of planning for the future and scant knowledge of business finances are two

I5 Interview with Dewi, Taipei. July 2019. 
important constraints that limit Indonesian immigrants in Taiwan. According to Ignaz, head of IPIT,

... in fact, the Indonesian migrant doesn't have a well-managed calculation on future planning; they [just] collect money, but the don't think seriously about their future plans as to what they would use their savings, and will instead consider this when they are home. ${ }^{16}$

Cassarino (2004) stated that, successful self-employment after returning to their hometown depends on worker's preparation while working abroad, perhaps even before their departure for the host country. According to Kevin, leader of One-Forty, when a migrant worker has a clear financial plan, their chance in establishing a business when they return home is much higher compared to when they have no plan at all. When there is no clear plan or when the plan their business when they return home, the plan to successfully opening a business is less likely to bear fruit, particularly for unmarried returned migrants with no family responsibilities because they tend to spend their income on personal consumption. As a consequence, NGOs and other institutions set up a migrant worker business school in their teaching programs, to teach the students business and financial planning concepts necessary to start and run a business. The biggest constraint is limitations on time and manpower as well as the wide range of training materials that prevent the programs to be conducted smoothly. Both NGOs and government institutions faced difficulties in spreading business know-how on to the workers because

I6 Interview with Ignaz, Taipei. September 2019. According to him, three socio-financial conditions underlay migrants' lack of concrete plans for their lives after they return home. First, they prioritize their incomes to pay off their debts before they leave Taiwan, meaning that their focus is on paying personal debt and saving income. Second, they spend money on personal items, such as gadgets and clothing, or on personal grooming, meaning that they have problems resisting cultural appeals to consuming. Third, they calculate their savings based on the idea that they will immigrate again to Taiwan because of financial challenges that they anticipate facing as return migrants. Ignaz explained that planning for and maintaining a financial strategy of entrepreneurship at home might seem to immigrants as far from what they originally expected. they have limited understanding of Mandarin. Another obstruction is that since none of them has ever started a business yet, the curriculum of the training is more theoretical than practical.

Karen $\mathrm{Hsu}$, the leader of GWO, pointed out some major constraints the NGO and government have to solve in order to develop an education for the migrant workers. There are four common problems often faced: I) Most training classes occur only in the big cities or at governmental vocational training centers and cater to a large group; 2) There is a limited room capacity, because most NGOs rented rooms or use public facilities; 3 ) High-cost of the training centers operations create losses for the NGOs, so they need support from partners; 4) Training given by the governments, NGOs and communities lack teaching staff who are willing to work voluntarily; 5) qualified teachers should be employed to teach vocational subjects, training and retraining of vocational teachers should be conducted to update their knowledge, skills, techniques and methodology of the vocational subject they are teaching. ${ }^{17}$

According to Hesti, a staff of GWO, migrant workers education is different with formal education. In the community-based education that the workers receive, teachers serve as a mentor who guide their learning process. Teachers need to work individually with students in the identification and planning purposes, the involvement of the community, and to help students learn from their experience. Therefore, orientation training for prospective teachers, and mentors from the community is also very important. To some extent, the government plays a role of a sponsor for the semi-annual programs for entrepreneurial training and support of the livelihood projects of returned migrants. These efforts are still limited in migrant groups and need to improve so that the trainings are more widely available so they could reach all of Indonesian migrant population in Taiwan. Indonesian and Taiwan governments, both of which have limitations, lack financial and human resources and the knowledge to handle most of the workers' problems. The en-

I7 Interview with Karen Hsu, Taipei. July 2019. 
trepreneurial training program initiated by the government is promising, but, unfortunately, it has not been evaluated for the application to future programs. Some workers considered that the training program as a charity, and referred to it as a 'gift' that provides temporary benefits with little long-term effect. ${ }^{18}$

\section{CONCLUSION}

Indonesian migrant worker vocational training and community-learning in Taiwan stand between knowledge production and capacity building activities. The activities are implemented in five major areas: I) the literacy of migrants working and living in Taiwan; 2) the development of community information and resource services (small library, newsletter, and social media networking); 3) the development of capacity building (short-term courses, skill-based training); and 5) the promotion of life-experience and skill/income generating migrants (e.g., entrepreneurship, agriculture innovation, or hobbies). The role of vocational education and migrant community-learning in Taiwan may be summarized as 'the bridge'. Without helping and distributing supplies and information in the migrant community, for instance, migrant workers would have no information to activities held by government or migrant communities. The role of the government, NGOs, and community-learning also can be seen as 'invisible agent' to build social solidarity (kesetiakawanan sosial) and togetherness (kebersamaan) among workers, especially in providing services for those who needs education, skill improvement, and social organization. Rather than seeing vocational education and community learning merely as participating in education activities only, it is important to see them as part of migrant empowerment institution. They play the role of a friend, acting as a third-party resource to help other workers in need. The practices of migrant vocational education and community learning in the host country are rarely seen as being capable empower workers and building their capacity. However, vocational education

I8 Interview with Hesti, Taipei. July 2019. and community learning have the resources to do so. Here we can understand the types of programs and its constraints that stakeholder can develop network within migrant communities and promote migrant skill improvement and provide a pathway for the workers' future as well.

\section{ACKNOWLEDGMENT}

Many thanks to the journal anonymous reviewer, Dr. Kai Otto Chang (Wenzao University) and Prof. Dr. Tsing Lung Tsay (Taiwan) for all helpful suggestions and comments to improve the idea of this paper, and the participants in the Wenzao International Conference on Southeast Asia Studies (Wenzao ICSEAS) "Southeast Asia: Global vs Regional vs Local”, Wenzao Ursuline University (WZU), Kaohsiung, Taiwan, October, I7-I9, 20I9. The research for this study was supported by a grant from the Taiwan Fellowship fiscal year 2019 .

\section{REFERENCES}

ADB, ILO, \& OECD. (2015). Building Human Capital through Labour Migration in Asia. Tokyo: ADB.

Bachtiar, P. P., \& Prasetyo, D. D. (2014). Return Migration and the Importance of Reintegration Policies. SMERU Policy Brief. Jakarta: The SMERU Research Institute.

Bachtiar, P. P, \& Tirtosudarmo, R. (2017). From domestic workers to care workers, understanding the dynamics of Indonesia's overseas labour mobility, Asia Pacific Journal of Social Work and Development, 27:3-4, I42-I58.

BNP2TKI. (2016). Laporan Kinerja Deputi Bidang Penempatan. Jakarta: BNP2TKI.

Cassarino, J. P. (2004). Theorizing Return Migration: The Conceptual Approach to Return Migrants Revisited. International Journal on Multicultural Societies (IJMS), (6)2, 253-279.

Cedefop (20Io). The development of national qualifications frameworks in Europe. Luxembourg: Publications Office (Cedefop working paper, 8). Available from Internet: http://www. cedefop.europa.eu/EN/Files/6ro8_en.pdf

Cedefop (20II). Employment-related mobility and migration, and vocational education and training. Luxembourg: Publications Office (Cedefop working paper, 9). Available from Internet: https://www.cedefop.europa.eu/ files/6ro9_en.pdf 
Chang, C., Salvatore, A., Lee, P. T., Liu, S. S., \& Minkler, M. (20I2). Popular Education, Participatory Research, and Community Organizing with immigrant Restaurant Workers in San Francisco's Chinatown: A case study. In M. Minkler (Ed.), Community organizing and community Building for Health and Welfare (pp. 246-264). New Brunswick, NJ: Rutgers University Press.

Cheng, I., \& Momesso, L. (20I7). Look, the World is Watching How We Treat Migrants! The Making of the Anti-Trafficking Legislation during the Ma Administration. Journal of Current Chinese Affairs, 46, I, 6I-99.

Everington, K. (2019). Migrant worker Count in Taiwan Climbs to 706,000, Indonesians largest Group. Retrieved from https://www. taiwannews.com.tw/en/news/3716487, access on 20 May 2019.

Farbenblum, B, et al. (2018). Transformative Technology for Migrant Workers: Opportunities, Challenges, and Risks. New Yotk: Open Society Foundations.

Ghofar, Abdul. (2019). Data Collection Placement and Protection of Indonesian Overseas Worker. Paper presentation Regional workshop on Strengthening the collection and use of international migration data in the context of the 2030 Agenda for Sustainable Development, Bangkok, 5 - 8 February 2019.

Huang, L. L., \& Douglass, M. (2008). Foreign Workers and Spaces for Community Life Taipei's Little Philippines in The Politics of Civic Space in Asia Building Urban Communities, Daniere, A., \& Douglass, M, (eds). London: Routledge.

Hung Chen, K. (20I4). Community Inhabitants' Attitudes on the Partitioning of Urban Space Derived from South-Eastern Asian Migrant Workers' Gathering in Urban Commercial Area-A Case Study on Tainan City, Kaohsiung City and Taichung City in Taiwan. Sociology Mind, 4(I), I5-23.

Huey-jen. (2007). Culture in the Borderlands: "Stories" of Southeast Asian Domestic Workers in Taiwan. Doctorate dissertation, Department of Ethnology, Heidelberg University.

International Labour Organisation (ILO). (2018). Policy Brief: Skills for Migration and Employment. Jakarta: ILO.

International Organization for Migration (IOM). (2009). Gender and Labour Migration in Asia. Switzerland: IOM.

Lan, P. C. (2003). Political and Social Geography of Marginal Insiders: Migrant Domestic Workers in Taiwan. Asian and Pacific Migration Journal, I(2), 99-I25.
Lan, P. C. (2006). Global Cinderellas. Migrant Domestics and Newly Rich Employers in Taiwan, Duke: University London.

Lin, J. H. (2017). 'Assisting You to Become a Local': NGOs and Constructed Foreign Spouses in Eastern Taiwan. Gender, Place \& Culture, doi:I 0.1080/0966369X.2017.1395819

Loveband, A. (2009). Nationality matters: Indonesian foreign domestic workers in contemporary Taiwan (PhD dissertation). University of Wollongong.

Lopega, D. (20I7). The Politics of Migrant Labour Policymaking: The Case of Taiwan. Retrieved from http://migratingoutofpoverty.dfid.gov. uk/files/file.php?name =lopega-the-politicsof-migrant-labour-policymaking-the-caseof-taiwan.pdf\&site $=354$ access on ig August 2019.

Mafruhah, I., Sarsito, T., \& Gravitiani, E. (20I2). “The Welfare of the Indonesian Migrant Workers (TKI) In the Land of a Malay Nation": A Socio-Economic Analysis". Southeast Asian Journal of Social and Political Issues, Vol. I, No. 2, March 20I2, pp. 246-27I.

OECD/ILO. (20I7). Skill Needs Anticipation: Systems and Approaches - Analysis of a Stakeholder Survey on Skill Needs Assessment and Anticipation. (Geneva), http://www.ilo.org/skills/ areas/skills-training-for-poverty-reduction/ WCMS_616207/lang--en/index.htm

Parreñas, R. S., Silvey, R., Hwang, M. C., \& Choi, C. A. (20I9). Serial Labor Migration: Precarity and Itinerancy among Filipino and Indonesian Domestic Workers. International Migration Review, 53(4), I230-I258. https://doi. org/Io.II77/or97918318804769

Randolph, G. (2015). Labor Migration and Inclusive Growth: Toward Creating Employment in Origin Communities. USA: Just]obs Network Inc

Susilo, W. (2010). Pendidikan Sebagai Agenda Perlindungan Buruh Migran Indonesia. http://migrantcare.net/wp-content/uploads/20i6/o9/ artikel_JP_migran_dan_pendidikan.pdf retrieved on August 20I9.

Syaiful, A. (2009, June II). Nestapa buruh migran. Retrieved from berita.liputan6.com/ read/2332I7/Nestapa.Buruh.Migran

Taiwan Panorama. (2018). The Growing Influence of an Indonesian Women's Association. Retrieved from https://www.taiwan-panorama.com/ en/Articles/Details?Guid= debiccfe-77d84a9o-b3eo-8497f3deda82\&Catl $d=4$ access at August 20I9. 
Tierney, R. (2008). Inter-ethnic and Labourcommunity Coalitions in class struggle in Taiwan since the Advent of Temporary Immigration. Journal of Organizational Change Management. 2I, 4, 482-496.

Tsai, Y. H., \& Hsiao, H. H. (2006). The nongovernmental organizations (NGOs) for foreign workers and foreign spouses in Taiwan: A portrayal. Retrieved from http://www.rchss. sinica. edu.tw/capas/publication/newsletter/ N33/33_oI-I.pdf.

Wagemakers, A.; van Husen, G.; Barrett, J.; Koelena, M. Amsterdam's. (2015). An innovative strategy to achieve and enhance the participation of migrant community-based organizations. Health Educ. J., 74, 4II-423.

Widyowati, R. (20I4). Social Relations and Interactions of Muslim Ethnic Minorities in Taiwan: Case Study of Indonesian Muslim and Chinese Muslim. Master thesis, International Program in Asia-Pacific Studies, National Chengchi University.

Wijayanti, H., \& Windiani, A. (20I6). Legal Protection and Advocacy for Indonesian Migrant Worker. Proceeding the 2nd International Multidisciplinary Conference 2016 November I5th, 20I6, Universitas Muhammadiyah Jakarta, Indonesia.
Yuniarto, P. R. (2015a). Indonesian Migration Industry in Taiwan: Some Socio-Economic Implications and Improvement Challenges. Jurnal Kajian Wilayah, 6(I), I7-33.

Yuniarto, P. R. (2015b). Culture, Structure, and Co-Ethnic Relations of Indonesians: Migrant Entrepreneurship in Taiwan. Asia-Pacific Social Science Review, I5 (2) 2015, 56-74

Yuniarto, P. R. (20I6a). Beyond Ethnic Economy: Religiosity, Social Entrepreneurship, and Solidarity Formation of Indonesian Migrants in Taiwan. Makara Hubs-Asia, 20I6, 20(I): I-I4

Yuniarto, P. R. (20I6b). Bridging People, Seizing the Future: Indonesian Migrant Entrepreneurs in Taiwan and Return-migrant Entrepreneurship in Malang, East Java Indonesia. Ph.D. Dissertation, Dept. of Social Anthropology, Graduate School of Humanities, Tokyo Metropolitan University

Yuniarto, P. R. (2018). Indonesian Return Migrants Entrepreneurship at Home Village: Knowledge Production and Living Strategy. Jurnal Kependudukan Indonesia, Vol. I3 No. 2, 89-I02. 
